\title{
X 線回折環分析装置によるピーリング損傷の評価
}

\author{
嘉村 直哉* 藤田 工* 佐々木 敏彦**
}

\section{Evaluation of Peeling by Using an Analyzer of X-Ray Diffraction Ring}

\author{
by
}

Naoya KamurA*, Takumi FustTA* and Toshihiko SASAKI**

This paper introduces the evaluation of rolling contact fatigue (RCF) under insufficient lubrication condition for carbonitrided bearing steel, JIS SUJ2.

The progression of RCF was evaluated based on equivalent stress, retained austenite and the degree of martensite grain orientation which were characterized by three parameters: $\sigma_{\mathrm{eq}}, \gamma_{\mathrm{R}}$ and $S / S_{0}$, respectively. We calculated $\sigma_{\text {eq }}$ using a tri-axial residual stress obtained by the Sasaki-Hirose method. The $S / S_{0}$ was defined as the variation of peak intensities for the central angle of the X-ray diffraction ring. In order to confirm quantitativity of $\gamma_{\mathrm{R}}$, two types of X-ray devices ware used. These parameters were compared with specimens subjected to standard heat treatment of SUJ2. As a result, the following knowledge was obtained.

Carbonitride caused larger residual stresses and delayed the beginning of increasing of $S / S_{0}$. In addition, the peeling area ratio at the number of cycles of $10^{6}$ was smaller as compared with standard heat treatment specimen. Furthermore the $\gamma_{R}$ remained until the end of the test. These results were due to the effect of nitrogen dissolved in steel.

\section{Key words:}

Rolling contact fatigue, Peeling, Rolling bearing, SUJ2, X-ray stress measurement, X-ray diffraction ring, Tri-axial stress, Retained austenite, Carbonitride

\section{1 緒言}

ピーリング損傷とは，希薄潤滑の状態で表面粗さの突 起が直接接触することで生じる, 表面起点型転動疲労損 傷の一種である。これまでに，著者らはピーリング損傷 に至る転動疲労の進行過程を, 2 次元検出器を有する $\mathrm{X}$ 線残留応力測定装置を用いて調查し, 転動疲労が表面の 残留応力の変化と結晶配向をともなう現象であること を明らかにするとともに，ピーリング損傷がせん断モー ドで進行している可能性を示した ${ }^{1), 2)}$.

近年，低粘度潤滑油の使用などにより転がり軸受の使 用環境は苛酷化している。 そのような使用環境での短寿 命を防ぐために様々な材料開発が行われてきた．軸受用 鋼では, 合金成分や熱処理の変更によってその対策をと ることが多く, 熱処理の変更をする場合の多くは浸炭窒 化処理を基本にした処理を行う 3),4)ため，転がり軸受に とって浸炭窒化処理は重要な技術である。そこで，本報 では浸炭窒化処理を施した試験片に対して同様の分析 を行い, 熱処理の違いが X 線測定值に及ぼす影響を調査 したのでその結果を報告する。

\section{2 二円筒転動疲労試験 \\ 2. 1 実験条件 \\ 試験はFig. 1 (a)に示す二円筒試験機を用いて，駆動側 の試験片を回転し，試験片間に発生する摩擦で従動側の 試験片を転動させる純転がり条件で行った。試験片の表 面は駆動側を鏡面，従動側を粗面に仕上げたので，以下 ではそれぞれ鏡面側, 粗面側と呼称する。潤滑油は, 無 添加タービン油(VG32)を染み込ませたフェルトパッド を回転中の試験片に接触させて供給した。}

Table 1 に試験条件を示す. 試験片の材質は JIS の軸受 鋼 2 種(SUJ 2)である. 条件 A では, 鏡面側に浸炭窒化処 理, 粗面側に標準的な焼入焼戻処理を施した試験片を用 いた．窒素はオーステナイトを安定化する効果がある ${ }^{5)}$ ので, 試験前の条件 A の鏡面側試験片の残留オーステナ イト量は条件 B より多かった。 なお，条件 B は前報 1) で実施した試験であり, 鏡面側, 粗面側ともに標準的な 焼入焼戻を施した試験片を用いている.

試験片形状 Fig. 1 (b) のような $\phi 40 \times t 12$ の円筒形状 で，軸方向の曲率半径は鏡面側がœ(ストレート), 粗面 側が $60 \mathrm{~mm}$ である.ピーリング損傷は表面粗さが小さい

原稿受理 平成29年12月8日 Received Dec. 8, 2017 @2018 The Society of Materials Science, Japan

* NTN (株) 先端技術研究所 テ 511-0867 桑名市陽だまりの丘 NTN Corporation Advanced Technology R\&D center, Hidamarinooka, Kuwana 510-0867.

** 正会員 金沢大学大学院 自然科学研究科 $\overline{7} 920-1192$ 金沢市角間町

Graduate School of Natural Science \& Technology, Kanazawa University, Kakuma-machi, Kanazawa 920-1192. 
側に発生する ${ }^{6)}$ ため, X 線測定による転動疲労の評価は 鏡面側試験片で実施した。なお，ピーリング損傷の程度 を定量化するため, 光学顕微鏡視野内に存在するはく離 部分の面積の割合（ピーリング面積率）を鏡面側試験片 表面で測定した.

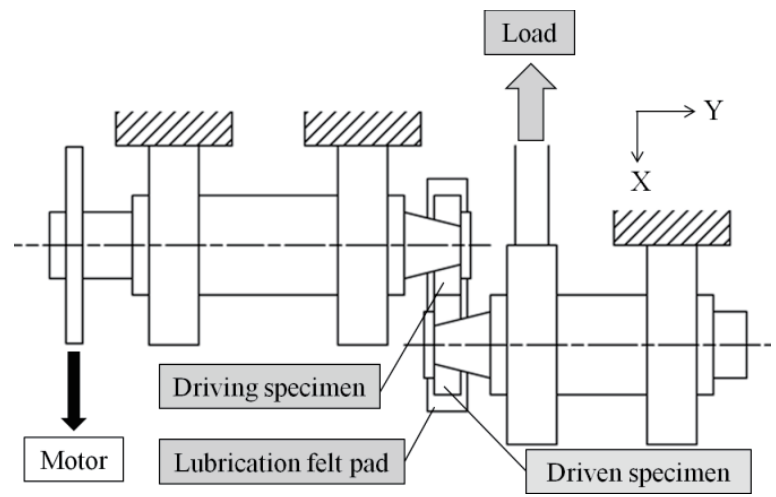

(a) RCF test rig.

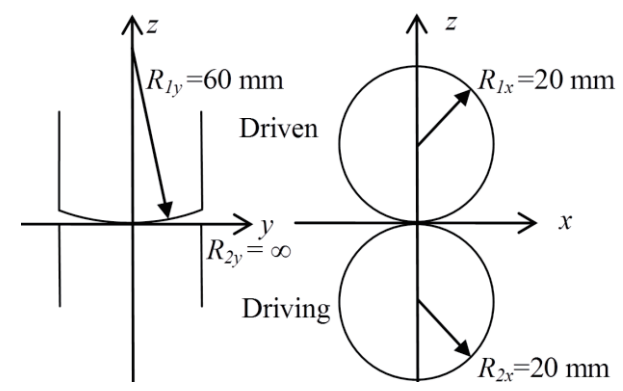

(b) Test specimens.

Fig.1 Schematic drawings of RCF test.

Table 1 Conditions of two-cylinder type test.

\begin{tabular}{|c|c|c|c|}
\hline & Condition A & Condition B \\
\hline \multicolumn{2}{|c|}{$P_{\max }, \mathrm{GPa}$} & \multicolumn{2}{|c|}{2.77} \\
\hline \multicolumn{2}{|c|}{ Rotation speed , min $^{-1}$} & \multicolumn{2}{|c|}{500} \\
\hline \multirow{2}{*}{$R_{\mathrm{q}}, \mu \mathrm{m}$} & Driving & 0.020 & 0.022 \\
\cline { 2 - 4 } & Driven & 0.895 & 0.987 \\
\hline \multirow{2}{*}{$\begin{array}{c}\text { Heat } \\
\text { treatment }\end{array}$} & Driving & Carbonitrided & \multirow{2}{*}{ Standard } \\
\cline { 2 - 3 } $\begin{array}{c}\text { Retained austenite of } \\
\text { driving specimen, } \%\end{array}$ & Standard & \multirow{2}{*}{8.2} \\
\hline \multicolumn{2}{|c|}{0.3} \\
\hline
\end{tabular}

\section{2. $2 \mathrm{X}$ 線測定条件}

$\mathrm{X}$ 線測定にはパルステック工業(株)製 $\mu-\mathrm{X} 360$ を使用し た.この装置は X 線検出器にイメージングプレート

（Imaging Plate; IP）を使用しており，回折環全周の情報 が単一入射で得られるので短時間で結晶配向の状態が 評価できる.また回折 X 線の $\psi$ 方向の走査が不要なため $\sin ^{2} \psi$ 法と比較して短時間で応力解析が可能である. 測 定条件を Table 2 に示す. 残留応力測定の際は $\mathrm{K}_{\beta}$ カット フィルタを使用しなかった．残留応力解析には 3 方向か らの X 線入射で三軸応力が得られる佐々木一廣瀬法 ${ }^{7}$ を用いた。測定の際は Fig. 2 に示す座標系をとり， $\psi_{0}=30 \mathrm{deg}$ で $\phi_{0}=0,90 \mathrm{deg}$ の 2 方向と, $\psi_{0}=0 \mathrm{deg}$ で $\phi_{0}=0 \mathrm{deg}$ の 1 方向の計 3 方向から X 線を入射した.

三軸残留応力解析に用いる無応力状態での回折角 $\left(2 \theta_{0}\right)$ は，条件 B と同じ熱処理を施した SUJ2 製のコロをやす りがけにより粉末にして巨視的応力を除去したものを 焼なましせずに試料とし, Nelson-Riley の外挿関数 ${ }^{8)}$ で 得られる格子定数 $d_{0}$ から算出した。 測定条件を Table 3 に示す. 使用した装置は(株)リガク製 Smart Lab で, 特性 $\mathrm{X}$ 線は $\mathrm{Co}-\mathrm{K} \alpha$ 線, $\mathrm{K}_{\beta}$ カットフィルタは鉄を使用した。

Fig. 3 に外挿関数のプロットを示す. Fig. 3 から求めた $d_{0}$ は $0.28677 \mathrm{~nm}$ であり,この值から算出した $\mathrm{Cr}-\mathrm{K} \alpha$ 線で の $2 \theta_{0}$ は $156.158 \mathrm{deg}$ となった. なお，外挿法に使用した 回折面は $\alpha^{\prime}-\mathrm{Fe}(200),(211),(220) て ゙ ，(110) は \gamma-\mathrm{Fe}$ および $\mathrm{Fe}_{3} \mathrm{C}$ のピークと重なるため解析には使用しなかった.

残留応力測定と同時に残留オーステナイト量測定も 実施した，測定条件を Table 4 に示す，管電圧，管電流 および X 線照射径は残留応力測定と同様である。なお, $\mathrm{K}_{\beta}$ カットフィルタにはバナジウムを用いた

転動接触面の結晶配向の程度を定量的に評価するた めのパラメータとして, X 線回折環の不均一さ $S / S_{0}$ を定 義する.ここで， $S$ は Fig. 4 に示すようにデバイリング の中心角 $\alpha$ に対する回折強度の標準偏差であり， $S_{0}$ は試 験前の $S$ の值とした.

Table 2 X-ray stress measurement conditions.

\begin{tabular}{|c|c|}
\hline Characteristic X-ray & $\mathrm{Cr}-\mathrm{K} \alpha$ \\
\hline Diffraction (hkl) & $\alpha^{\prime}$-Fe $(211)$ \\
\hline Filter & None \\
\hline $2 \theta_{0}$, deg & 156.158 \\
\hline Tube conditions & $30 \mathrm{kV}, 1 \mathrm{~mA}$ \\
\hline X-ray irradiated area ,mm & $\phi 2$ \\
\hline Incident angle $\psi_{0}, \mathrm{deg}$ & 0,30 \\
\hline Exposure time, $\mathrm{s}$ & 72 \\
\hline
\end{tabular}

Table 3 Lattice constant measurement conditions.

\begin{tabular}{|c|c|}
\hline Characteristic X-ray & Co-K $\alpha$ \\
\hline Diffraction (hkl) & $\alpha^{\prime}-\mathrm{Fe}(200), \quad(211), \quad(220)$ \\
\hline $\mathrm{K}_{\beta}$ filter & $\mathrm{Fe}$ \\
\hline Tube conditions & $40 \mathrm{kV}, 135 \mathrm{~mA}$ \\
\hline X-ray irradiated area, $\mathrm{mm}$ & $\phi 1.5$ \\
\hline
\end{tabular}

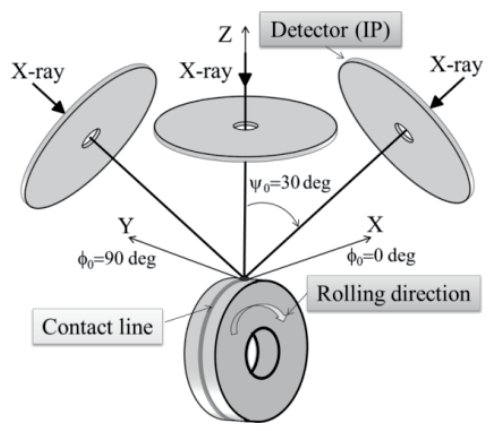

Fig. 2 Coordinate system in X-ray stress measurement for driving specimen. 


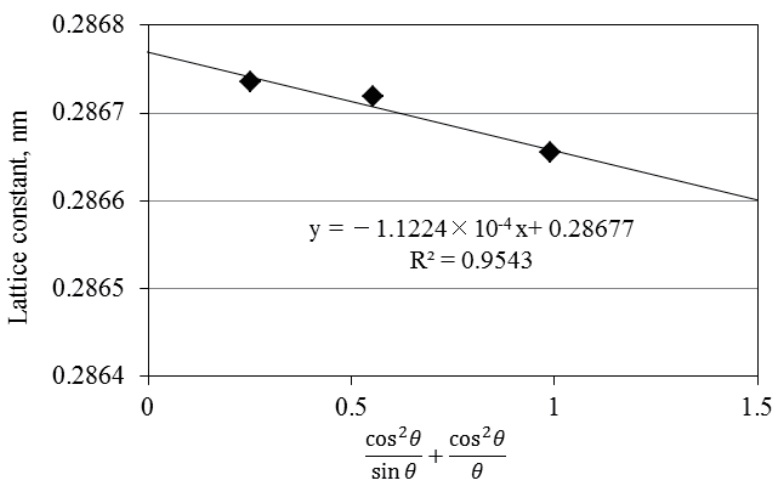

Fig. 3 Plots of Lattice constant against $\left(\cos ^{2} \theta / \sin \theta+\cos ^{2} \theta / \theta\right)$.

Table 4 Retained austenite measurement conditions for $\mathrm{X}$-ray diffraction ring analyzer using two diffraction planes.

\begin{tabular}{|c|c|}
\hline Characteristic X-ray & $\mathrm{Cr}-\mathrm{K} \alpha$ \\
\hline Diffractions (hkl) & $\begin{array}{r}\alpha^{\prime}-\mathrm{Fe}(211) \\
\gamma \text {-Fe }(220)\end{array}$ \\
\hline $\mathrm{K}_{\beta}$ filter & $\mathrm{V}$ \\
\hline Incident angle $\psi_{0}, \mathrm{deg}$ & 0 \\
\hline Exposure time, $\mathrm{s}$ & 90 \\
\hline
\end{tabular}

$\mathrm{X}$-ray diffraction ring
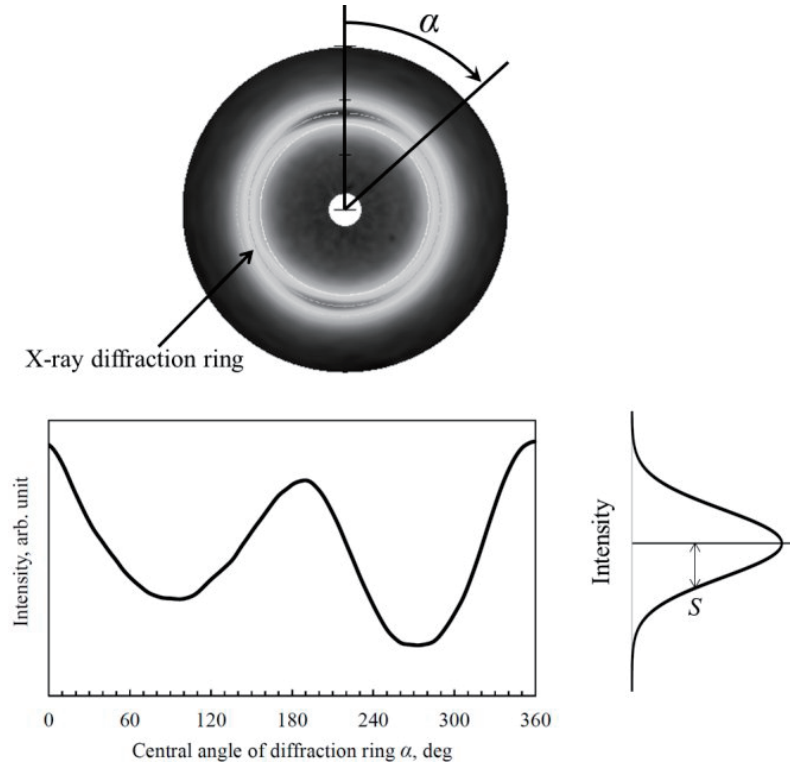

Fig. 4 Standard deviation $S$ of the diffraction ring intensities at the central angle $\alpha$.

\section{3 実験結果}

\section{1 表面の損傷状態}

Fig. 5 に条件Aと条件B $の$ 試験後 (負荷回数 $1 \times 10^{6}$ 回) の鏡面側試験片転動面の光学顕微鏡写真をそれぞれ示 す。条件Aは条件Bに比べてピーリング損傷が少なく, ピーリング面積率は条件Aで $0.074 \%$ ，条件Bで $2.5 \%$ で あった。

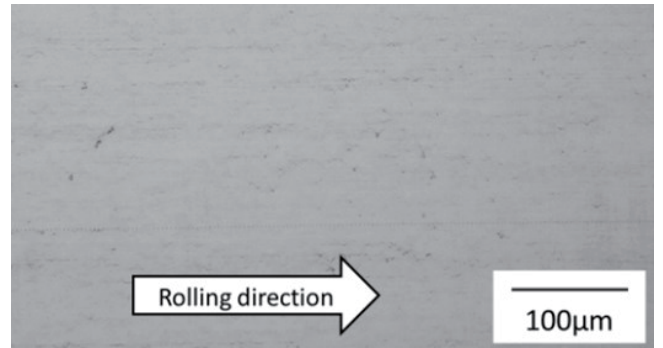

(a) Condition $\mathrm{A}$

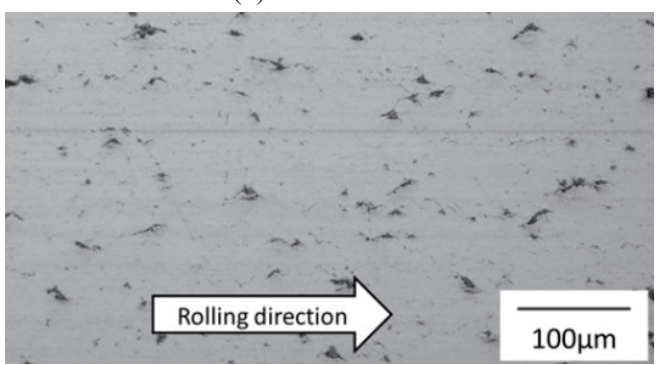

(b) Condition B

Fig. 5 Optical microscopy images at RCF surface for driving cylinders.

\section{2 X 線回折環}

Fig. 6 に条件 A，Fig. 7 に条件 B の試験前後の X 線回 折環を示す. 条件 A の試験前のバックグラウンドが高く なっているのは, $\gamma$ - $\mathrm{Fe}(311) の$ 回折が強いためである. 試 験後の回折強度分布を Fig. 8 に示寸. 条件 A の回折強度 が条件 B に比べて全体的に低いのは, 後述のように条件 A は残留オーステナイトや析出物の影響で $\alpha^{\prime}-\mathrm{Fe}(211)$ の 回折強度が相対的に低下していることや, 両者の疲労進 行度に差があるためである。また，条件 A，条件 B とも に結晶配向の影響で回折強度分布が不均一になってお り, $\alpha=200 \mathrm{deg}$ および $\alpha=340 \mathrm{deg}$ 付近の回折が強くなっ ていることがわかる. Fig. 9 に負荷回数と $S / S_{0}$ の関係を 示寸. 条件 $\mathrm{A}$ は負荷回数 $10^{4}$ 回, 条件 B は負荷回数 $10^{3}$ 回以降に $S / S_{0}$ が増加した. 負荷回数 $10^{6}$ 回での $S / S_{0}$ は条件 Bのほうが大きくなった。

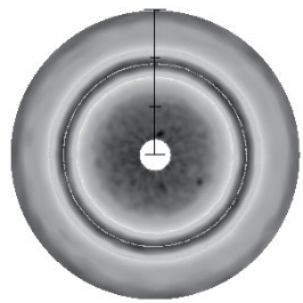

(a) Before testing

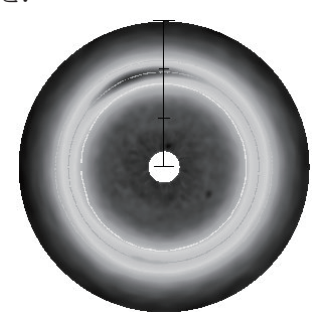

(b) $10^{6}$ cycles
Fig. 6 Diffraction rings of the testing condition A.

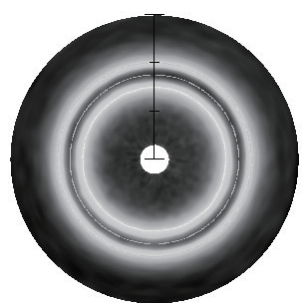

(a) Before testing

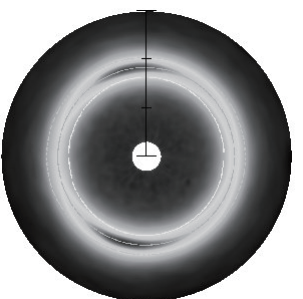

(b) $10^{6}$ cycles
Fig. 7 Diffraction rings of the testing condition $\mathrm{B}$. 


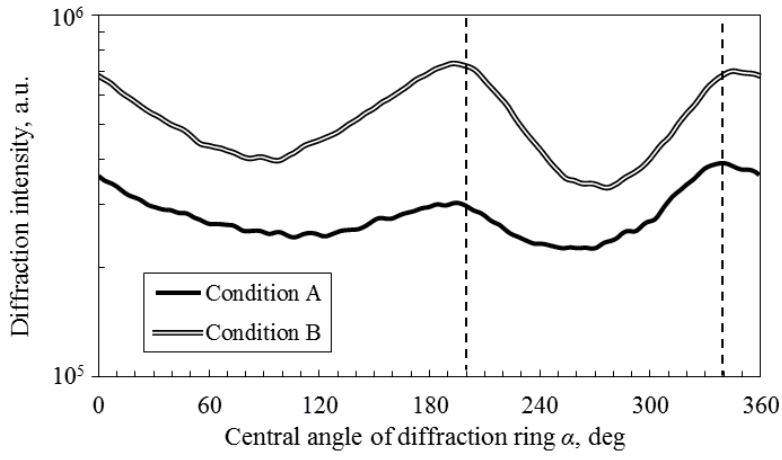

Fig. 8 Diffraction intensity distributions at $10^{6}$ cycles.

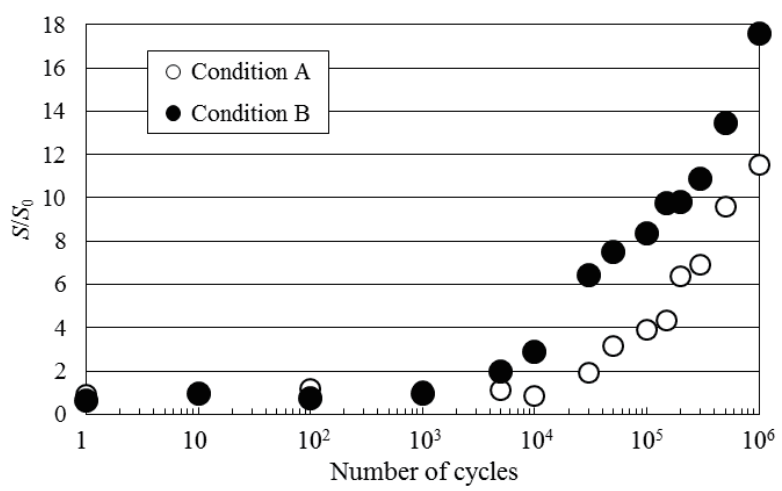

Fig. 9 Relationships between $S / S_{0}$ and the number of cycles.

\section{3 残留応力}

試験前の鏡面側試験片表面の残留応力を Table 5 に示 す.研磨により形成される圧縮残留応力は条件 A と条件 B でほぼ等しかった。 なお，条件 B の残留応力は Fig. 3 から求めた $d_{0}$ を用いて再計算したため, 垂直応力成分が 前報 ${ }^{1)}$ で示した值と異なっている.

垂直応力成分の負荷回数による変化を Fig. 10 に示す. 条件 B のピーリング損傷の起点となる微小き裂とピー リング損傷の増加に起因する応力解放(負荷回数 $2 \times 10^{5}$ 回)まで, 両条件の垂直応力には大きな差は見られなかっ たが， $\sigma_{\mathrm{x}}, \sigma_{\mathrm{y}}$ は条件 $\mathrm{A}$ の方が大きい圧縮残留応力となる 傾向があった。 なお， せん断応力については図示しなか ったが，その值に条件 A と条件 B で大きな差は無く, 試験中も $\pm 100 \mathrm{MPa}$ 以内の変化しかなかった。

転動中の残留応力が軸受鋼の降伏応力に対してどの 程度に達しているかについて評価するため，3 軸の残留 応力から相当応力 $\sigma_{\mathrm{eq}}$ を計算した. 負荷回数に対する相 当応力の変化を Fig. 11 に示す. 条件 B では $10^{3}$ 回の負荷 で相当応力が飽和し，1073 MPa となった。一方，条件 A は $5 \times 10^{3}$ 回で相当応力がいったん飽和し，その值は 1152 $\mathrm{MPa}$ で，条件 $\mathrm{B}$ の飽和した值と比較して 7.4 \%大きい. その後, 条件 B では上記の応力解放が発生するまで相当 応力が増加した。

Table 5 Residual stresses before testing.

\begin{tabular}{|c|c|c|c|c|c|c|c|}
\hline Testing condition & $\sigma_{\mathrm{x}}$ & $\sigma_{\mathrm{y}}$ & $\sigma_{\mathrm{z}}$ & $\tau_{\mathrm{xy}}$ & $\tau_{\mathrm{xz}}$ & $\tau_{\mathrm{yz}}$ & $\sigma_{\mathrm{eq}}$ \\
\hline A & -1066 & -1175 & -607 & 57 & 32 & -4 & 534 \\
\hline B & -1023 & -1056 & -516 & 36 & 5 & -10 & 528 \\
\hline
\end{tabular}

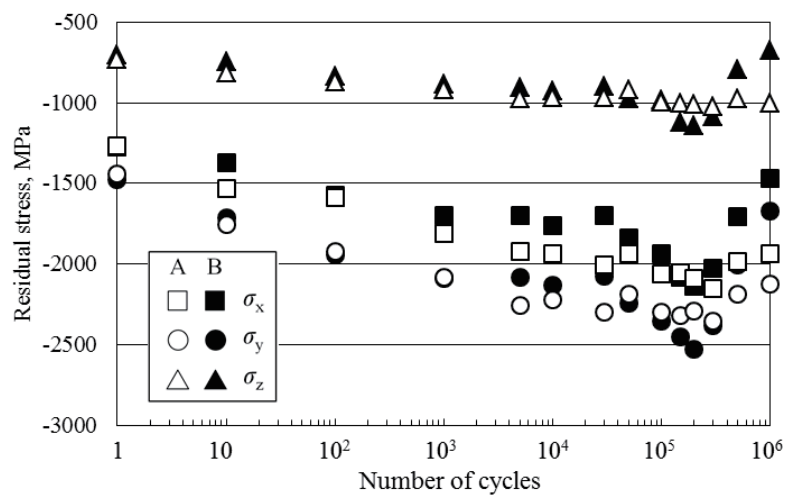

Fig. 10 Relationships between residual stresses and the number of cycles.

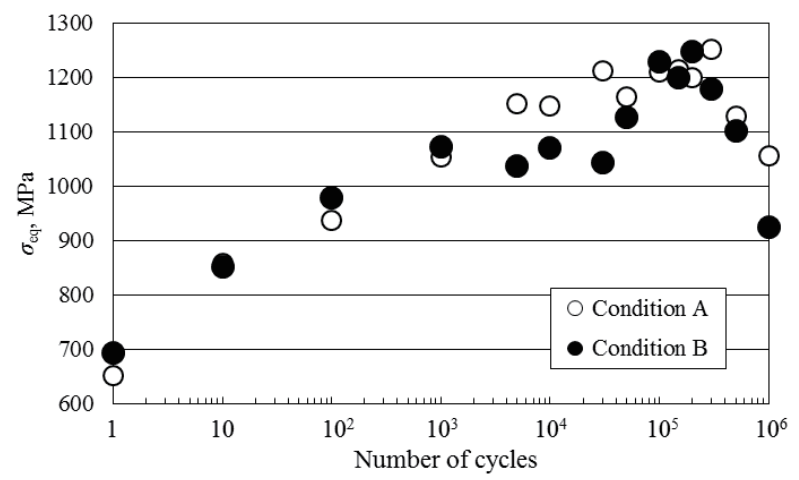

Fig. 11 Relationships between equivalent stresses $\sigma_{\text {eq }}$ and the number of cycles.

\section{4 残留オーステナイト}

Fig. 12 に負荷回数と残留オーステナイト量の関係を 示す.試験前の残留オーステナイト量は, 条件 A が $32 \%$, 条件 B が $8.2 \%$ であった. 条件 B では $10^{3}$ 回の負荷で残 留オーステナイト量はほとんど 0 となった. 疲労の進行 によって残留オーステナイトが増加することはないの で, $2 \times 10^{4}$ 回以降は条件 B の残留オーステナイト量測定 を省略した. 条件 A は, 負荷回数 $5 \times 10^{3}$ 回時点で $15.6 \%$, 試験終了時点でも $6.6 \%$ の残留オーステナイトが検出さ れた.

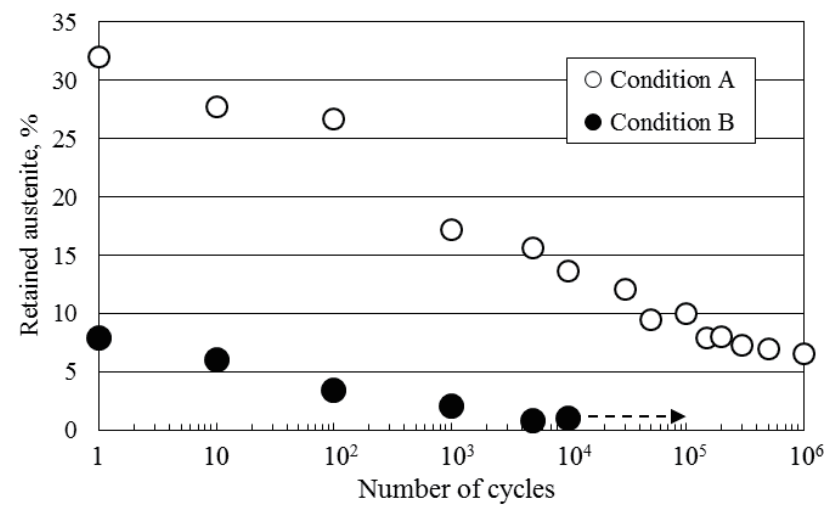

Fig. 12 Relationships between retained austenite and the number of cycles. 


\section{5 残留オーステナイト定量性の評価}

前項の残留オーステナイト量は $\alpha^{\prime}-\mathrm{Fe}(211)$ と $\gamma$ - $\mathrm{Fe}(220)$ の回折線の積分強度比から得られた值である。しかしな がら，軸受鋼に浸炭窒化処理を施すと，通常の焼入をし たものに比べて炭窒化物などの析出物が多くなる ${ }^{9)}$. し たがって, 浸炭窒化処理品については炭窒化物の回折線 が $\alpha^{\prime}-\mathrm{Fe}(211)$ と $\gamma$ - $\mathrm{Fe}(220)$ の回折線と重畳している可能性 があり, 残留オーステナイトの定量性の悪化が懸念され

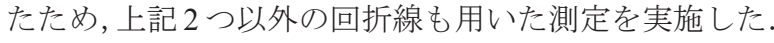

測定条件を Table 6 に示す. 使用した装置は格子定数 の測定と同じく，Rigaku 社製 Smart Lab である。事前の 定性分析により， $\mathrm{Fe}_{3} \mathrm{C}$ の回折線が $\alpha^{\prime}-\mathrm{Fe}(211)$ の裾に重な ることがわかっている，なお，定性分析時に窒化物の回 折線は検出されず，また $\mathrm{Fe}_{3} \mathrm{C}$ の回折強度は試験前後で ほとんど変化していないことがわかったため $\mathrm{Fe}_{3} \mathrm{C}$ のピ 一クは解析の際に考慮せず, $\gamma$ 相の体積分率を求めた. 測定は試験前および $10^{6}$ 回負荷後（試験後）の転動接触 部最表面について実施した。測定の際には試料を面内に 回転させ配向の影響を緩和した。 $\gamma$ 相の体積分率は次式 10)で計算した。

$$
V_{\gamma}=\frac{1}{\left\{\left(\frac{I_{\alpha^{\prime}} R_{\gamma}}{I_{\gamma} R_{\alpha^{\prime}}}\right)+1\right\}} \times 100
$$

ここで,

$V_{\gamma}: \gamma$ 相の体積分率(\%)

$I_{\alpha \prime}, I_{\gamma}: \alpha^{\prime}$ 相, $\gamma$ 相の積分強度

$R_{\alpha^{\prime}}, R_{\gamma}: \alpha^{\prime}$ 相, $\gamma$ 相の単位体積あたりの理論回折強度

Fig. 13 に測定で得られた回折プロファイルを示す.試 験前後のプロファイルを比較すると，試験後は $\gamma$ 相の各 回折面の回折強度が低下していることから，転動疲労に よって残留オーステナイト量が減少していることがわ かる。これらのプロファイルから各相を定量した結果を Table 7 に示す. $\mu$-X360 の測定值については，回折環全 周から得られる 500 個の測定データの標準偏差 $(1 \sigma)$ を 求めて信頼限界とした。 Table 7 より，2つの装置で測定 した值はおおよそ一致しており，Fig. 12 における条件 A の残留オーステナイトの変化に及ぼす $\mathrm{Fe}_{3} \mathrm{C}$ のピークの 重なりの影響は考慮する必要が無いと判断した.

Table 6 Measurement conditions for evaluation of quantification of retained austenite using multiple diffraction.

\begin{tabular}{|c|c|}
\hline Characteristic X-ray & $\mathrm{Co}-\mathrm{K} \alpha$ \\
\hline Diffraction (hkl) & $\begin{array}{c}\alpha^{\prime}-\mathrm{Fe}(200), \quad(211) \\
\gamma \text {-Fe (200), (220), (311) }\end{array}$ \\
\hline $\mathrm{K}_{\beta}$ filter & $\mathrm{Fe}$ \\
\hline Tube conditions & $40 \mathrm{kV}, 135 \mathrm{~mA}$ \\
\hline X-ray irradiated area, $\mathrm{mm}$ & $\phi 1.5$ \\
\hline
\end{tabular}

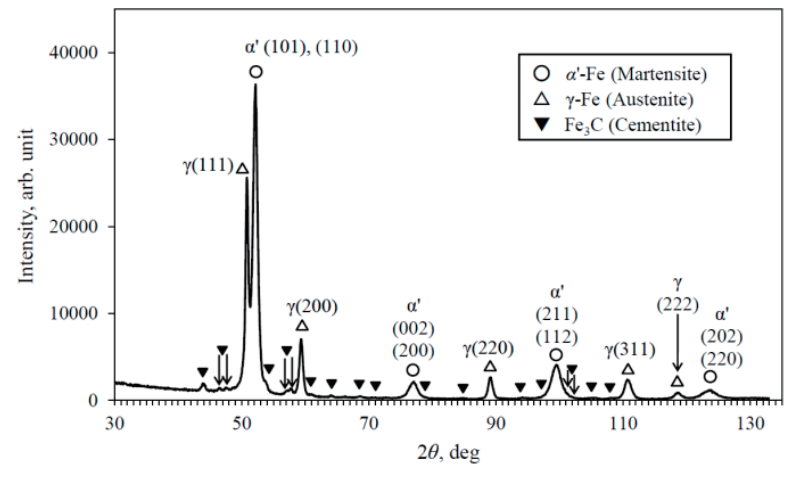

(a)Before RCF

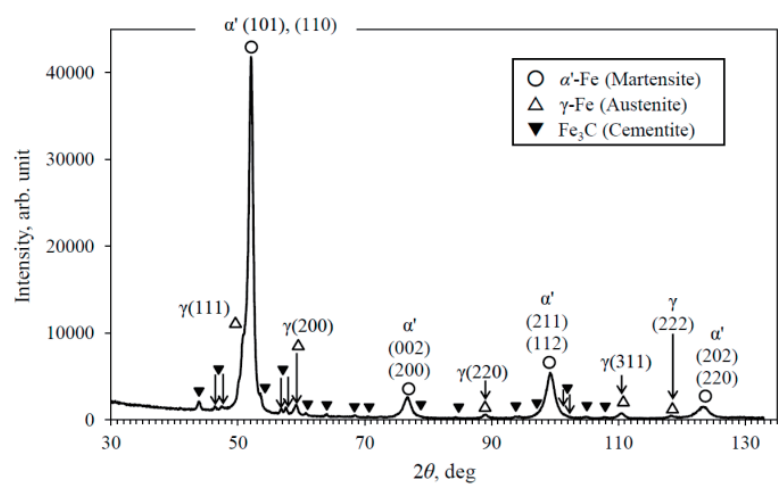

(b) After RCF

Fig. 13 X-ray diffraction patterns of before and after RCF.

Table 7 Comparison of retained austenite measured by two diffraction method and multiple diffraction method.

\begin{tabular}{|c|c|c|}
\hline & Two diffraction & Multiple diffraction \\
\hline Before RCF & $32 \pm 2.2 \%$ & $33 \%$ \\
\hline $\begin{array}{c}\text { After RCF } \\
\left(10^{6} \text { cycles }\right)\end{array}$ & $6.6 \pm 1.7 \%$ & $7 \%$ \\
\hline
\end{tabular}

4 考察

\section{1 残留応力の変化}

両条件とも試験開始直後から残留オーステナイトが 減少していくが，これは加工誘起変態によるものである. オーステナイトからマルテンサイトへ変態すると体積 膨張が起こる. また, 表面粗さ突起の接触による塑性変 形でマルテンサイトにも圧縮応力が生成されるため, 両 条件とも試験の初期段階では圧縮残留応力が増加する. 条件 $\mathrm{A}$ の負荷回数 $5 \times 10^{3}$ 回時点での相当応力が条件 $\mathrm{B}$ に 比べて大きくなったのは, 残留オーステナイトが多く存 在していたため加工誘起変態による圧縮残留応力の増 分が大きかったことと, 浸炭窒化で固溶した窒素の効果 で降伏点が上昇したため ${ }^{11)}$ と考えられる.

条件 A では，負荷回数 $10^{6}$ 回でのピーリング面積率が 小さかったが，これは浸炭窒化品の圧縮残留応力の増加 が表面の塑性変形(き裂の発生)とその後の進展を抑制し ている可能性が考えられる，今後，両者の表面の塑性変 形の状況やき裂進展の違いを調査し，X 線分析の結果と の関係性を議論していく必要がある. 


\section{2 残留オーステナイトの変化}

条件 B では負荷回数 $10^{3}$ 回以降, 残留オーステナイト がほぼ 0 になった。 それに対して, 条件 A では負荷回数 $5 \times 10^{3}$ 回時点で $15.7 \%$ の残留オーステナイトが存在し ており, $10^{6}$ 回負荷後も 0 にはならなかった。条件 A で は，条件 B と同様に，圧縮残留応力による塑性変形の抑 制効果を超えて，結晶配向が進行するほどの高い接触応 力の繰返しが継続している，それにもかかわらず，条件 A では，条件 B よりも 3 けた以上多い負荷回数でも，残 留オーステナイトはすべて加工誘起変態しきらない。こ れは, 浸炭窒化処理で固溶した窒素によって残留オース テナイトが加工誘起変態に対して安定になったことを 示唆している.

\section{4. $3 \mathrm{X}$ 線回折環の不均一さ $\left(S / S_{0}\right)$ の変化}

条件 A では条件 B に比べて $S / S_{0}$ が増加し始める時期 が遅かった. 条件 A は残留オーステナイトが多く存在し ているため疲労の過程においてマルテンサイトの結晶 格子が受ける変形が条件 B に比べて小さくなり ${ }^{12)}$, 結晶 配向の開始が遅延されたものと推察する。また，析出物 および結晶格子間に侵入した炭素と窒素により転位の 移動が阻害されること ${ }^{13)}$ で, 結晶格子の回転が生じにく くなったことも条件 A の結晶配向の進行に影響してい ると考えられる。なお， $S / S_{0}$ は配向の方位については評 価できないパラメータなので，今後は方位の情報を含ん だパラメータによる結晶配向の定量化方法を検討する.

\section{5 結言}

浸炭窒化処理した軸受鋼製円筒試験片（浸炭窒化品） を作製し, 希薄潤滑条件での転動疲労の進行を X 線分析 で評価した。その結果，以下の知見が得られた。

1）浸炭窒化品では, 標準熱処理した試験片に比べて大 きい圧縮残留応力が生成され, 相当応力で比較する と $7.4 \%$ 大きかった．浸炭窒化品は残留オーステナ イト量が多いため, 加工誘起変態による膨張量が多 いことに加え, 窒素の固溶によって降伏点が上昇し たことが原因と考えられる。

2) また, 負荷回数 $10^{6}$ 回でのピーリング面積率が標準 熱処理した試験片に比べて小さかった. 浸炭窒化に よる圧縮残留応力の増加が表面粗さ突起の接触に よる表面の塑性変形(き裂の発生)とき裂発生後の 進展を抑制している可能性が考えられる.

3）浸炭窒化品では, 試験終了まで残留オーステナイト が残存しており, 加工誘起変態に対する残留オース テナイトの安定性が高かった。

4）浸炭窒化品では, 標準熱処理した試験片に比べて X 線回折環の不均一さの変化が小さかった. 残留才一 ステナイトと固溶元素の効果で結晶配向の進行が 遅延された可能性が考えられる。

\section{参 考 文 献}

1) N. Kamura, T. Fujita and T. Sasaki," Effect of residual stress on peeling of rolling bearings ", Proceedings of The 50th Symposium on X-Ray Studies on Mechanical Behaviour of Materials, pp.21-24(2016).

2) T. Fujita, N. Kamura, Y. Maruyama and T. Sasaki, "Evaluation of rolling contact fatigue using X-ray diffraction ring", Materials Performance and Characterization, Vol. 5, No. 1, pp. 23-37(2016).

3) H. Kurabe and T. Araki, "Rolling fatigue characteristics of carburized or carbonitrided $1 \% \mathrm{Cr}$ Steel at Elevated Temperatures", Tetsu- to-Hagane, Vol.53, No.11, pp.151-154 (1967)

4) C. Ooki, " Improving rolling contact fatiguelife of bearing steels through grain refinement ", SAE Technical Paper, 2004-01-0634(2004)

5) D. P. Koistinen, "The generation of residual compressive stresses in the surface layers of through-hardening steel components by heat treatment", Transactions of ASM, Vol.57, pp.581-588(1964).

6) M. Tokuda, S .Ito and H. Muro, "Evaluation of lubricants by a peeling test ", Journal of Japanese Society of Tribologists, Vol. 22, No.6, pp.347-351(1977).

7) T. Sasaki, S. Takahashi, K. Sasaki and Y. Kobayashi, “A study on improvements in multiaxial stress analysis with area detector type diffraction method", Transactions of The Japan Society of Mechanical Engineers, Series A, Vol.75, No.750, pp.219-227(2009).

8) J. B. Nelson and D. P. Riley, "An experimental investigation of extrapolation methods in the derivation of accurate unit-cell dimensions of crystals", Proceedings of the Physical Society, Vol.57, No.3, pp.160-177(1945).

9) N. Mouri and K. Taguchi, "Improvement of wear resistance by heat treatment for carburizing steel", NTN Technical Review, No.76, pp.17-22(2008).

10) N. D. Cullity, " Element of X-ray diffraction (new edition)", Translated by G. Matsumura, pp.374-385 (1980) Agne.

11) S. Takeuchi, "On the substitutional solid-solution strengthening in iron alloys", Tetsu- to-Hagane, Vol.55, No.1, pp.69-83 (1969).

12) H. Hishiki, T. Hori, H. Kohno, H. Kawabe and M. Uemura, "The effect of retained austenite upon the life of steel balls", Journal of the Japan Society of Precision Engineering, Vol.44, No.11, pp.23-29(1978).

13) S. Takeuchi, "Kesshososeiron (crystal plasticity)", pp.148-182(2013)Uchida Rokakuho Publishing. 